\title{
O discurso das Tidda': dramaturgas aborígenes australianas
}

\section{Tradução: Carolina Gosch Figner de Luna, Kysy Amarante Fischer e Lívia Sudare de Oliveira ${ }^{3}$}

Todas as indígenas compartilham a experiência de serem mulheres e indígenas numa sociedade que as deprecia. Consequentemente, existirão temas comuns, característicos e dominantes no posicionamento das mesmas. Tais temas incluem o compartilhamento do legado da desapropriação, racismo e sexismo, assim como anos de resistência e substituição das imagens depreciativas, construídas sobre elas, por imagens que as definam e que sejam construídas por elas mesmas; além da continuação do ativismo como mães, irmãs, tias, filhas, avós e líderes comunitárias, bem como a negociação de políticas sexuais através e entre culturas. Tal ponto de vista não nega a diversidade de experiências das indígenas, visto que experiências concretas diferentes moldam as suas relações com essas questões centrais. Levantar uma perspectiva sobre a mulher indígena também requer a consciência, o respeito e o cumprimento do protocolo cultural indígena. (Aileen Moreton-Robinson) $)^{4}$.

\footnotetext{
1 Tiddas é uma palavra indígena que significa "irmã", usada no nordeste da Austrália. (nota nossa).

2 Maryrose Casey é professora associada à Monash University (AUS) e PhD em Theatre and Drama da La Trobe University (AUS). A sua tese Creating frames; contemporary indigenous theatre 1967-97 foi publicada pela University of Queensland Press. O livro foi premiado com o Australasian Drama, da Theatre and Performance Association Rob Jordan Prize e co-vencedor da Association for the Study of Australian Literature Walter McRae Russell Award.

${ }^{3}$ Carolina Gosch Figner de Luna e Kysy Amarante Fischer são bolsistas CAPES, do Programa de Pós-Graduação em Teatro (Mestrado), da Universidade do Estado de Santa Catarina-UDESC. Ambas são orientandas da Profa. Dra. Maria Brígida de Miranda. Lívia Sudare de Oliveira é bolsista CAPES, do Programa de Pós-Graduação em Teatro (Doutorado), da Universidade do Estado de Santa CatarinaUDESC e orientanda da Profa. Dra. Vera Collaço.

4 MORETON-ROBINSON, Aileen Researching whiteness: some reflections from an indigenous woman's standpoint. Hecate V. 29 N. 2 , (Out. 2003), p. 75 .
} 


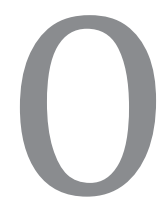
s dramaturgos indígenas têm ocupado um papel importante dentro do teatro australiano, tanto para o público indígena como para o não-indígena. Um dos méritos de suas realizações têm sido a introdução e a presença contínua nos palcos locais de vozes que contestam implícita e explicitamente as representações fixas e coletivizadas de indígenas australianos.

Um ponto importante que Aileen Moreton-Robinson levantou acima, e Marcia Langton enfatiza em suas discussões sobre os artistas indígenas e a sua recepção, refere-se a diversidade indígena, não apenas individualmente como seres humanos, mas também em termos de ideias e trabalho criativo que apresentam ${ }^{5}$. Fazendo parte desses debates, um grupo de dramaturgas indígenas tem desafiado construções homogeneizadas sobre os povos indígenas, contestando as representações fixas e coletivizadas sobre as mulheres indígenas. Usando humor e emoções fortes, autobiografias, biografias e as histórias de suas comunidades, essas mulheres têm se engajado corajosamente com polêmicas e questões preocupantes subjacentes tanto na relação entre pessoas indígenas e nãoindígenas quanto dentro de comunidades indígenas.

A citação acima, de Moreton-Robinson, refere-se a uma discussão igualmente apropriada para as acadêmicas e dramaturgas indígenas australianas como para quem faz teatro. Elas incluem em suas discussões, mulheres de várias formações e experiências com fortes semelhanças decorrentes de suas heranças culturais e vivências como indígenas. Pensam como grupo: de mulheres e indígenas australianas. Escrevem como tal e o seu trabalho é recebido dentro deste contexto, enredado tanto pela questão de raça quanto de gênero.

Uma estudante euro-australiana que estava estudando dramaturgia australiana veio falar comigo sobre uma montagem de uma peça de Odette Best, uma dramaturga

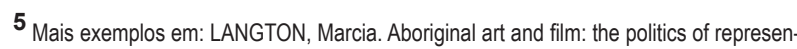
tation. In: GROSSMAN, Michele (Org.). Blacklines, MUP, 2003. indígena. A peça era True (2004). Best tem formação em saúde indígena e vem desenvolvendo paralelamente um trabalho direcionado na escrita e experimentação de filmes. Nadine McDonald, a diretora artística do Kooemba Jdarra Indigenous Theatre, depois de ler o tratamento para o roteiro de um curta que Best havia baseado em um sonho, propôs que ela retrabalhasse a história para o teatro ${ }^{6}$. Best aceitou a proposta e True tornou-se parte dos três anos do programa de trabalho do Kooemba. ${ }^{7}$ Durante o processo, True foi selecionada para ser discutida na Australian National Playwrights' Conference (ANPC), em 2002. O curta manteve-se como uma parte de todo um trabalho desenvolvido por Best. O resultado final desta produção combinou o teatro e a projeção do curta. Sequências de memória incorporaram gravações de crianças indígenas dentro de instituições, que foram projetadas no cenário na última parte da peça. A projeção incluía também gravações do arquivo familiar da tia de Best $^{8}$.

A trama da peça descreve a jornada de três personagens principais: Toby, uma trabalhadora social num centro médico, Leon - que estuda Artes Performáticas - e Noah, um estudante de Direito. Através destes personagens, a peça explora a complexa questão da identidade indígena no ambiente urbano contemporâneo. Os três indivíduos questionam suas identidades pessoais e culturais e tentam compreender o seu lugar na comunidade, no contexto da definição aceita de "aboriginalidade". Atualmente, a definição mais amplamente utilizada para quem é ou pode ser identificado como aborígene - ou torres strait islander - é principalmente social. Um indígena australiano é entendido como o descen-

\footnotetext{
${ }^{6}$ Kooemba Jdarra é uma companhia teatral controlada por indígenas, dedicada a produzir trabalhos de artistas indígenas australianos.

7 O desenvolvimento de programas é uma importante parte da missão da filosofia da fundação Kooemba a fim de apoiar o desenvolvimento de novas vozes indígenas. Para um roteiro de três partes seriam necessários três estágios. No primeiro ano existe 0 Creative Development, onde o foco é direcionado para a pesquisa e elaboração de texto. 0 segundo estágio é chamado de New Work Development e centra-se no desenvolvimento das ideias e do rascunho do texto. Ao final do segundo ano, os textos do New Work são apresentados como leituras públicas. 0 terceiro estágio culmina na encenação profissional da produção.

${ }^{8}$ True foi dirigida por Nadine McDonald e produzida pela companhia Kooemba Jdarra, em Brisbane, na Metro Arts, no ano de 2004.
} 
dente de um nativo da Austrália, sendo, portanto, identificado e reconhecido como indígena pelos membros de uma comunidade aborígene - ou torres strait islander. ${ }^{9}$

Apesar da nomenclatura "aborígine" ser aceita pela comunidade indígena e de ser mais adequada do que as sessenta e sete definições anteriormente desenvolvidas pelos europeus para se referir aos indígenas australianos, esta definição apresenta problemas de adequação para milhares de indígenas que foram retirados de suas origens ${ }^{10}$. Aqueles que, por conta das várias políticas governamentais, foram removidos de suas famílias e comunidades, institucionalizados e tiveram seus contatos com suas culturas e comunidades indígenas negados. ${ }^{11}$ Estas dificuldades são agravadas pelas experiências traumáticas resultantes das tentativas de adultos que tentam se reconectar com suas famílias e comunidades. Em True, Best revela alguns dos desafios enfrentados pelas pessoas que foram removidas quando crianças. Como consta no material de divulgação, a peça explora a seguinte questão: "se os nossos vínculos com a nossa cultura já foram rompidos, como iremos resgatar aquilo que já foi perdido?"12. Best passou por esse dilema em suas experiências pessoais, pois ela foi retirada de sua família nos anos sessenta. Assim como a personagem Toby, Best foi adotada por um indígena australiano koombumerri e sua esposa anglo-celta. ${ }^{13}$

A produção engajou-se com esta conflituosa situação e questionou a identidade em uma série de níveis, tanto visuais quanto verbais. Os personagens representaram

\footnotetext{
${ }^{9}$ Essa definição resultou de uma decisão da High Court e é aceita pela Australian Commonwealth Government e por suas autoridades. Também é a definição preferida pela maioria dos aborígines e torres strait islanders. Ver: LANGTON, Marcia. Well I heard it on the radio, and I saw it on the Television, Australian Film Commission, 1993

10 MCCORQUODALE, John. The Legal Classification of Race in Austrália, Aboriginal History, V. 10, N. 1, 1986. p. 7-24

11 Nos anos de 1900 as inquirições de uma Comissão de Direitos Humanos e de Oportunidades Igualitárias descobriu que, no período de 1910 a 1970, uma em cada três, inicialmente e uma em cada dez, posteriormente, crianças aborígenes haviam sido removidas de suas famílias, a maioria pelo uso da força ou sob coerção. Ver Bringing Them Home: Report of the National Inquiry into the Separation of ATSI Children and their Families. (Commissioner Ronald Wilson) Human Rights and Equal Opportunity Commission, 1997

12 True, Flyer, Kooemba Jdarra Indigenous Theatre, Brisbane, 2004.

13 Tradicionalmente as terras do povo koombumerri são ao sul da ilha de Stradbroke Island e de Southport, Queensland.
}

uma ampla e divergente gama de tipos indígenas, desde os que tiveram diferentes ligações com a cultura e comunidades indígenas, até aqueles que não tiveram quase nenhum contato com suas raízes, como é o caso de uma das personagens, a moça que acabava de descobrir a sua ancestralidade aborígene; ou como Leon, que nasceu e foi criado dentro de uma comunidade indígena. A seleção dos atores indígenas antecipou as categorizações de indígenas australianos pela cor da pele por demonstrações visíveis de que a cor da pele não é de importância primária para a identificação, ainda que seja um tema de discussão recorrente. A indigeneidade na peça, assim como nas comunidades, é reconhecida em termos de conexão cultural, de comunidade e de auto-identificação. Os indivíduos que estavam mais conectados às suas comunidades tinham a pele mais clara, já os tipos menos fáceis de identificar ou serem identificados como indígenas tinham, por sua vez, a pele mais escura. Durante todo o texto, o fato de que a pele escura foi usada e considerada como um marcador de "aboriginalidade" especialmente, mas não exclusivamente, pelas comunidades não-indígenas, foi vinculado à uma gama de perspectivas. Assim como McDonald, a diretora descreve: True examina e questiona a noção de identidade baseada na diferença da cor de pele e na classificação do governo. A peça também explora como algumas pessoas indígenas são categorizadas com base na cor de sua pele, dentre as comunidades indígenas e não-indígenas. ${ }^{14}$

Por décadas a cor da pele foi considerada pelos euro-australianos como a principal marca da "aboriginalidade", cuja classificação estava inserida em definições legislativas. A ênfase em noções de raça baseadas em características físicas, tais como a cor, justificou a remoção de crianças com peles mais claras, pois se partiu do pressuposto que elas poderiam ser integradas. A cor da pele foi usada para ditar a vida das pessoas e limitar suas escolhas. Peter Read relata um exemplo das situações que defi-

14 "Daring and compelling festival fare", National Indigenous Times, 18 Ago. 2004 
nem as pessoas de acordo com o efeito que a cor da pele causa:

Em 1935, um homem aborígene de pele clara, parcialmente descendente de indígenas, foi expulso de um hotel por ser aborígene. Ele retorna ao seu lar num abrigo missionário e sua entrada é recusada porque ele não era um aborígene. Ele tentou retirar seus filhos, mas foi dito que ele não poderia porque eles eram aborígenes. Ele caminhou até a próxima cidade onde foi preso por ser um vagabundo aborígene e foi colocado na reserva local. Durante a Segunda Guerra Mundial ele tentou alistar-se, mas foi dito que ele não poderia, porque era aborígene. Ele mudou de estado e se uniu aos aborígenes. Depois da guerra, ele não poderia adquirir um passaporte sem permissão, porque ele era aborígene. Ele recebeu a licença da Aborigines Protection Act e foi dito que ele não poderia ficar muito tempo visitando os seus parentes na reserva porque ele não era aborígene. Foi negada a sua entrada no Clube RSL porque ele era aborígene. ${ }^{15}$

A acadêmica euro-australiana reagiu com rejeição à trama de True baseada no que ela considerava como "normal" para os indígenas australianos. Este entendimento do que era "normal", combinado com a crença ativa de que o trabalho foi criado principalmente, se não exclusivamente, para o público não-indígena, deixou a euro-australiana irritada e frustrada com a peça. Tanto quanto eu poderia julgar a descrição do que ela "viu" da peça, ficou claro que as suas premissas e expectativas a impediram de enxergar o que estava no palco ou ouvir o que era dito. Entre as suas objeções à True, a afirmação de que a protagonista feminina não era uma indígena australiana "normal" porque ela era uma trabalhadora social articulada e de classe média, acaba destacando um dos desafios contínuos enfrentados por escritoras indígenas australianas. Essa objeção estava

15 Peter Read citado em Unfinished Business: An overview of community attitude research conduzido para o Conselho pela Reconciliação Aborígine, 1996. conectada à crença da acadêmica de que, para invocar a cultura e a identidade indígena, uma pessoa tinha que estar excluída ou fora da Austrália convencional. Uma outra contestação ou resistência substancial à trama da peça também decorre de suas concepções sobre "aboriginalidade". Ela assumiu que a cor da pele era um, se não o mais importante, marcador de tal termo. Ela havia se debatido com a imagem da pessoa com a pele mais clara ser identificada e aceita como aborígene, e a pessoa com a pele mais escura não. Esta resistência afetou literalmente o modo como a acadêmica euro-australiana recebeu a peça, pois no seu entendimento, um personagem de pele clara definitivamente era um não-aborígene. Isto, apesar de extensas trocas e diálogos sobre o seu grupo e as respostas de outros personagens. Ela finalmente resolve alguns de seus problemas com a produção, ao julgar que o elenco da peça havia sido selecionado através da utilização de uma política de casting daltônico. Ou seja, todos foram selecionados sem levar em conta as características físicas e o resultado foi puramente acidental.

A acadêmica era inteligente e bem informada, com uma ampla experiência cultural na Austrália e na Ásia, e esta reação não era só dela. Ela estava dando voz à reação de um grupo de estudantes que tinham visto a apresentação na mesma noite. Esta resposta, além de indicar que eu preciso repensar as minhas estratégias de ensino, demonstra a força das representações arraigadas de indígenas australianos, e como estas representações moldam as auto-representações indígenas contemporâneas. Para mim, estando na posição de euro-australiana, e escrevendo sobre artistas indígenas australianos, a reação da acadêmica serve como um bom lembrete para que eu esteja consciente dos meus próprios pressupostos arraigados. O fato também chama a atenção para os pressupostos gerais euros-australianos sobre quem cria a obra e por quê, e o impacto potencial dos mesmos.

$$
\text { A criação de Toby como uma mulher }
$$


forte, independente financeiramente, segura e competente, feita por Best, confronta a imagem de "aboriginalidade" dos alunos e de como os artistas indígenas devem representar-se para o público não-indígena. A acadêmica sentiu que os artistas indígenas deveriam apresentar problemas dentro das comunidades indígenas e representar esses povos como vítimas indignas. Esta expectativa surgiu, em parte, de um dos pressupostos arraigados da acadêmica, de que o teatro indígena era principalmente voltado para as audiências não-indígenas.

Kyas Sherrif, a atriz Murri que interpretou Toby, a personagem feminina principal em True, aponta: "como nós sorrimos, como nós interagimos, onde a dor está, é o que não discutimos" ${ }^{\prime 16}$ Sherriff afirma que a peça consiste em fortes personagens e observações de questões culturais que são "partes do dia-a-dia da existência" de indígenas australianos que vivem nessa situação. Para ela, a peça é sobre a vida cotidiana e os "problemas sobre os quais nós não falamos, as negações e, é claro, as verdades e mentiras". A peça foi produzida pela Kooembra Jdarra, uma companhia de teatro indígena. Para Shrerrif, um dos grandes "presentes" das companhias, controladas por indígenas, é a capacidade de prover oportunidade para australianos indígenas e não-indígenas de se "conectarem". Esta ponte de comunicação é importante no sentido em que se apoia no entendimento mútuo. No entanto, este entendimento mútuo demanda que a audiência não-indígena seja ativamente engajada com a questão, e que busque adquirir conhecimento e compreensão acerca de experiências que eles não possuem. A peça True é focada na dinâmica das relações, mas como Sherriff bem levanta "os aborígenes possuem uma dinâmica diferente". É de um outro ponto, no que se refere à dinâmica, experiência cultural e história, que as mulheres indígenas australianas falam.

Essas mulheres falam em um contexto no qual são dominantes as representações

16 "A true look at Kyas Sherriff", National Indigenous Times, 29 Set. 2004. As próximas citações foram retiradas dessa entrevista. pré-existentes que precisam ser confrontadas e contrariadas. Mudrooroo discute que, na dramaturgia australiana, personagens aborígenes são costumeiramente utilizados como uma "variante do destino" que não possui controle, voz ou esperança. ${ }^{17}$ Isso se aplica particularmente nas representações de mulheres australianas indígenas. Não há insuficiência de exemplos em trabalhos feitos por euro-australianos para justificar a análise feita por Mudrooroo, e a questão da representação tem sido intensamente contestada. No trabalho de autores não-indígenas, o aborígene representa "o lado trágico e impossível de prever do encontro com a violência, injustiça e pobreza, o esmagamento de aspirações, a negação da beleza, a ridicularização e a falta de liberdade de um indivíduo para determinar o seu próprio destino" ${ }^{18}$ Novamente, essa prática se aplica particularmente às representações das mulheres indígenas. A maioria das representações de mulheres indígenas australianas nos trabalhos de euro-australianos nos últimos cem anos tem sido consistentemente silenciosa e desprovida de poder em face à agressão euro-australiana.

Apesar de ter havido variações entre essas representações, em uma larga escala, as personagens de mulheres indígenas são enquadradas como vítimas silenciosas. Nos trabalhos de algumas dramaturgas euroaustralianas, esta impotência não tem sido completa, tem havido alguma subversão desta imagem e o silêncio tem servido enquanto base para uma resistência limitada. Na primeira metade do século, documentos sociais com objetivos políticos de diferentes posições, como Brumby Innes (1927), Katherine Susannah Pritchard e Men without wives (1938), de Henriquetta Drake Brockman demonstraram a impotência das mulheres indígenas, mesmo quando indicavam a habilidade individual de negociar entre as restrições. Tais peças tem como tema central a posição das mulheres, indígenas e não-indígenas, nas instâncias do

\footnotetext{
17 MUDROOROO, Narrogin. Writing from the Fringe, Hyland House, 1990. p. 121.

18 MUDROOROO, Narrogin.Writing from the Fringe, Hyland House, 1990. p. 167.
} 
interior. Ambas as peças refletem o medo colonialista em relação à população indígena local e explora o uso e abuso sexual de mulheres indígenas por homens euroaustralianos.

Em Men without wives, a personagem Channa, uma jovem indígena se comunica efetivamente, apesar de seu silêncio, de forma humorística e também ameaçadora. O silêncio é particularmente poderoso no final do primeiro ato, quando Channa é descrita na rubrica como: "furtiva e ganhando tempo com o festival", dentro da própria casa. ${ }^{19}$ Como Drake-Crockman, Pritchard estava tratando de sua própria experiência vivida em uma estância. Sua peça, Brunby Innes, fala sobre três mulheres: duas indígenas - Polly e Wylba - e uma euro-australiana, May; todas à mercê de Brumby. Elas são, de acordo com ele: "suas éguas". ${ }^{20}$ As mulheres aborígenes usam o silêncio e seu próprio dialeto para se afirmarem dentro dos parâmetros da dominação de Brumby. Por exemplo, na última cena, Wylba usa sua matriz linguística para abusar de Brumby, enquanto ele está se gabando sobre o fato de ela ser cativa. Wylba, que tem treze anos, foi sequestrada e teve a família punida por tentar resgatá-la, é descrita como: "astuta e empertigada insolentemente na entrada da porta" ao mesmo tempo em que ela diz para Brumby: "waly marri, booketerra, kundi-kundi spa". ${ }^{21}$ Estas palavras podem ser traduzidas como: "malvado, desprezível, fedorento, vergonha, vergonha".

The Man from Muckinupin (1979), de Dorothy Hewett, é outra peça de uma autora euro-australiana, geralmente recebida pelo público e pela crítica euro-australianos como uma peça que traz uma ruptura radical do costumeiro modo de representação. A indígena Toque de Piche é a personagem "noite", espelhando e duplicando a personagem "dia" euro-australiana. Toque de Piche fala, mas a sua vida é literalmen-

\footnotetext{
${ }^{19}$ DRAKE-BROCKMAN, Henrietta. Men without wives. Angus and Robertson, 1955,p. 19

${ }^{20}$ PRITCHARD, Katherine Susannah. Brumby innes and bid me to love. Currency, 1974 p. 97.

${ }^{21}$ PRITCHARD, Katherine Susannah. Brumby innes and bid me to love. Currency, 1974.p. 100
}

te trancada na escuridão e a personagem é geralmente interpretada por uma atriz euro-australiana.

Na maioria das peças escritas por dramaturgos não-indígenas, a ação e o desenlace são efetivamente predeterminados. Estas representações definem as mulheres indígenas como objetos sexuais dos homens euro-australianos, presas a eles por conta da pobreza, desprovidas de educação e recursos, bem como sem voz política ou social. Em diversos aspectos, as representações das mulheres indígenas têm se tornado mais restritas com o passar do tempo. Em Too young for ghosts (1991), Janis Balodis usa personagens de mulheres indígenas como exemplo de impotência. Ele utiliza a técnica de espelhamento das experiências das personagens europeias sobre o estupro e a falta de poder, com uma encenação dos sequestros e estupros das mulheres aborígenes. ${ }^{22}$ Dentro deste espelhamento, um aspecto importante é levantado: as mulheres aborígenes não têm como se comunicar. Outro exemplo é o uso que Andrew Bovell faz de personagens de mulheres indígenas em Holy day (2001). Uma personagem, Obediência, é o exemplo clássico das gerações roubadas. $\mathrm{O}$ silêncio preenche a peça, pois sua língua é cortada no final. A outra indígena é presa e mantida cativa, onde é espancada, amarrada e depois executada. ${ }^{23}$ Essas mulheres, como Mudrooroo sugere, são representantes apenas da impotência e do silêncio. Ademais, a mensagem passada é que, ainda que elas resistam, mulheres indígenas não possuem outra opção além de sofrer, aguentar e lidar com este sofrimento.

Algumas notáveis exceções aconteceram em algumas peças escritas entre os anos de 1990 e 2000. Por exemplo, existe a peça Radiance, de Luis Nowra, escrita em 1995. Há o trabalho de Julie Janson com Black mary e Gunjies, ambas de 1996. Black mary traz a história dramática e real de Maryanne, uma fora da lei que era aborígene. Maryane não é desconhecida pela História,

\footnotetext{
22 Janis Balodis, Too Young for Ghosts, Currency, 1991. p. 27.

${ }^{23}$ Andrew Bovell, Holy Day, Currency/Playbox, 2001.
} 
mas a sua história é geralmente ofuscada pela do seu companheiro Capitain Thunderbolt. Esta peça é baseada na pesquisa de Janson sobre heranças orais aborígenes e arquivos da imprensa. Gunjies estreou em 1993, ano internacional dos povos indígenas. O título da peça é Koori, que significa polícia. A narrativa central fala de Aranda, uma garota koori urbana que frequenta o ensino médio. A peça segue a sua jornada através de trágicos eventos que a transformam - de uma ingênua colegial em uma jovem mulher atenta e poderosa politicamente.

Tais exceções são normalmente o resultado do diálogo entre os povos indígenas e o dramaturgo não-indígena. Entretanto, são poucas e não muito frequentes. Dramaturgas indígenas são também confrontadas por outro lado do legado do passado australiano. Marcia Langton aponta que: “a forma mais fácil e natural de racismo na representação é o ato de fazer o outro invisível" ${ }^{24}$ Essa exclusão de mulheres indígenas da maioria das peças, que se passam na Austrália, reforça as representações fixas quando elas estão presentes, e adiciona mais desafios aos já enfrentados, pelas dramaturgas indígenas. No trabalho de muitos dramaturgos indígenas, as mulheres geralmente são relegadas a um papel específico. Este papel é normalmente bem diferente daqueles tipos encontrados em peças euro-australianas. As mulheres são estilizadas, carregadas de sofrimento, fortes, fonte de recursos e âncora para a família ${ }_{\iota}$ como no trabalho de Jack Davis. ${ }^{25}$

As peças de mulheres indígenas confrontam e contestam essas representações, assunções e especulações no contexto de uma ampla estrutura de relações interculturais. As dramaturgas indígenas da Austrália, tais como Oodgeroo, nos anos de 1960 e 1970, e Eva Johnson, nos anos de 1970 e 1980, criaram trabalhos para o palco dando vozes às histórias de mulheres indígenas e suas auto-representações. Apesar de suas tentativas e seu intuito de acesso

24 Langton, 'Aboriginal art and film: the politics of representation'. p.113.

25 Por exemplo o personagem Dolly in Jack Davis, The Dreamers, Currency, 1983. aos palcos terem sido inicialmente de um sucesso limitado, nos de 1990 e 2000 as dramaturgas indígenas não só ganharam este acesso, como também reivindicaram um importante espaço para a criação.26 Para todos os dramaturgos indígenas, o acesso para produções era inteiramente controlado por companhias e festivais indígenas.

Anne Marshall argumenta que: "à sobrevivência em um mundo branco racialmente discriminatório, demanda o conhecimento em tradução, performance e auto-representação que nos fortaleça como mulheres indígenas." 27 Nos anos de 1990, um grupo de mulheres indígenas demonstrou tal conhecimento através do uso de diversas formas teatrais, formas essas que hoje são associadas a elas (monólogos e formas de contação de histórias). Por meio de suas escritas e criações, essas dramaturgas e artistas apresentaram vozes fortes, provocativas e alternativas, além de imagens de "mulheres de experiência" fora, dentro e através do convencional. As escritas impulsionaram e situaram os limites das representações. Ao fazer isso, elas apresentaram uma quantidade de mulheres fortes e ativas como personagens centrais de seus próprios dramas; mulheres que não são vítimas passivas do racismo ou do sexismo, mas agentes ativas, usando os recursos que possuem, no intuito de estimular a criação de possibilidades e um futuro potencial para elas mesmas e para outras.

Questões sobre falta de poder e abuso não são e não podem, dadas às experiências de muitas australianas indígenas, ser ignoradas no trabalho das dramaturgas indígenas. No entanto, esta questão é tratada de forma diferente e individualizada. Um dos aspectos ilustrados na escrita de um número de mulheres é a importância da espiritualidade tradicional como fonte de força. As questões relacionadas aos homens têm sido observadas e discutidas

\footnotetext{
${ }^{26}$ Para maiores discussões sobre a posição das dramaturgas indígenas na segunda metade do século XX, ver Maryrose Casey, Creating Frames: Contemporary Indigenous Theatre, UQP, 2004: 252-259

27 Anne Marshall, 'The Velvet Glove,' review of Talkin' Up to the White Woman: Indigenous Women and Feminism by Aileen Moreton-Robinson, Southerly, V 62 No 2 (Summer 2002): 187.
} 
em escritos antropológicos. Em contraste com a estrutura de respeito pelos homens e suas conexões com as práticas tradicionais, as questões concernentes às mulheres tem sido tratadas como se nem mesmo existissem. Apesar dessa concepção determinada sobre elas, algumas dramaturgas têm explorado nos palcos o papel das práticas tradicionais na vida das mulheres indígenas contemporâneas.

Com o devido respeito pelos protocolos da comunidade, Merril Bray, de Eastern Arrente, tem explorado a realidade brutal do abuso sexual e vitimização de mulheres indígenas a partir do ponto de vista da força e do apoio que as mulheres podem extrair da espiritualidade tradicional e do compartilhamento de conhecimentos femininos.28 Bray é dramaturga e artista plástica. Ela fez a sua primeira exposição de arte em Tandanya, Adelaide, em 1999, durante o Come Out Festival. Ela foi premiada com a bolsa Tandanya/Art. AS Aboriginal Artists Fellowship. A sua primeira peça, Our mob, estreou em Alice Springs, em 1991, com membros da comunidade local sob a direção de Richard Walley. No ano seguinte, Bray foi co-autora do projeto piloto de uma comédia cujo tema era centrado nas experiências e tribulações de uma estação de rádio aborígene. Our mob foi apresentada no ANPC/Aboriginal Conference 1993. Em seguida, Bray escreveu Mechanics for the spirit, em 1993, uma peça sobre a importância da nutrição do espírito.

Mechanics for the spirit explora a relação que se desenvolve entre duas mulheres aborígenes, uma jovem e outra idosa, que são literalmente jogadas juntas em uma cela de uma prisão em mesmo momento. ${ }^{29}$ Através das histórias das duas mulheres, o texto reflete a questão da perda feminina e a vulnerabilidade, tanto física quanto emocional, bem como com o apoio espiritual para as questões femininas. Depois que um sargento da polícia tenta estuprar a jovem

${ }^{28}$ As terras tradicionais dos arrentes ocidentais ficam em Hartzs Range, território do norte.

${ }^{29}$ BRAY, Merrill. Mechanics of the spirit. Directed by Noel Tovey, Theatre in the Raw, Illbijerri and Playbox, Beckett Theatre, Malthouse, 3 March, 1997; BRAY, Merrill. Mechanics of the spirit. Unpublished manuscript, 1994. Playbox archives. menina, a mulher mais velha, Aggie, revela uma forte conexão com a espiritualidade aborígine. Enquanto ela oferece conforto a jovem mulher e dá a ela força através das conexões tradicionais, fica claro que Aggie é um espírito ou um fantasma. Em 1995, a peça estreou em $A N P C$, sob a direção de Noel Tovey. Em 1997, uma nova versão retrabalhada de Mechanics of the spirit estreou publicamente no palco como parte da temporada Playbox/Ilbijerri de leituras em Melbourne. Depois Mechanics of the spirit foi produzida para o Adelaide Festival em 2000, como parte da apresentação dupla chamada Spirit, time and place; a outra peça apresentada foi Somewhere in the Darkness (1996) de Ray Kelly, dirigida por Tovey.

Um momento poderoso na peça é quando as duas mulheres irrompem sobre o palco e realizam uma dança feminina tradicional do povo arrente. A dança é introduzida e conduzida pelo fantasma de Aggie. O farfalhar delicado de folhas e o menear dos movimentos da dança reivindicam um espaço calmo e positivo, preenchendo o palco com uma diferente abordagem de possibilidade. A presença de Aggie e sua habilidade de cuidar e dar conforto à jovem mulher, que está sofrendo naquele momento, muda a representação de uma longa linhagem de mulheres abusadas para uma imagem em que um sentido de sobrevivência é dominante, uma sobrevivência que apoia a resistência e o futuro. Como Peta Tait e Elizabeth Schafer observaram, nos trabalhos de escritores indígenas para o palco, a herança cultural tradicional e o conhecimento funcionam, tanto no nível simbólico como no metafórico. ${ }^{30}$ Ambos os níveis são importantes, mas há também outro nível, a conexão ativa e literal entre o passado e o presente, entrelaçados em um senso individual de identidade e identificação cultural.

As culturas tradicionais têm sido usadas de maneira problemática em relação às construções de "aboriginalidade" vindas de fora e à classificação de artistas indíge-

\footnotetext{
30 TAIT, Peta ; SCHAFER, Elizabeth (Orgs.). In: and Feminisms, Currency Press, 1997,p. xiii.
} 
nas e do seu trabalho. Conexões ou falta de conexões com uma espécie de forma musealizada de cultura tradicional e "pré-contato" têm sido usadas como uma forma, muitas vezes excludente, de autenticar o trabalho dos artistas indígenas. Os termos de validação requerem uma demonstração tangível da relação entre a arte contemporânea indígena e "a transmissão da tradição através das gerações". ${ }^{31}$ Helen Gilbert discute este fenômeno em relação às primeiras produções da Bangarra Dance Company, inspirada em alertas de Gareth Griffith sobre o "mito da autenticidade como outra forma de discurso colonialista, através da construção de legitimidade em 'desejos' culturais externos ao invés de prática indígena". Gilbert afirma que este processo "reduz a cultura aborígene aos seus artefatos reproduzíveis negando a validade da criação, que reflete a experiência vivida" dos indígenas australianos contemporâneos e urbanos..$^{32}$ Este processo tem criado, por vezes, a base para uma hierarquia de "autenticidade" que reifica as práticas culturais tradicionais em detrimento dos desenvolvimentos contemporâneos. Isso, muitas vezes, resultou no desmerecimento de artistas indígenas contemporâneos e urbanos que foram estigmatizados por não serem artistas aborígenes "reais" ou "autênticos". Tanto os críticos nacionais e internacionais nas artes do espetáculo têm usado esta distinção. ${ }^{33}$

O enquadramento problemático das práticas tradicionais no trabalho de artistas indígenas tende a trazer a incorporação de referências ou práticas tradicionais como separada dos artistas e do presente. A peça de Bray se engaja com esta situação problemática de várias maneiras. Ela efetivamente reivindica uma ligação forte entre o passado e o presente para um indígena. Esta reorientação em direção à perspectiva

\footnotetext{
31 LENDON, Nigel ; CARUANA, Wally. The Wagilag Sisters, Art and Australia. V. $35 \mathrm{~N}$ 1, 1997, p 87

32 GILBERT, Helen. Sightlines: Race, Gender and Nation in Contemporary Australian Theatre, Michigan UP, 1998, p. 74-75

33 Ver: ROBERTS, Rhoda. Sweet Dreams. Review, Weekend Australian 13-14 Set. 1997 p. 20; GRAY, Bill. Bangarra Dance: A Talent for Tourism. p. 30. Disponivel em: http:// www.csmonitor.com/durable/1997/08/20/21feat/feat.5html. Acesso em: 29 ago.1997.
}

de um indígena contemporâneo, contesta as construções musealizadas e o enquadramento destas construções como marcadores de "aboriginalidade" e a diferença para o público não-indígena. Bray não incorpora imagens e práticas tradicionais como "marcadores" de "aboriginalidade", mas explora ativamente o significado potencial e a contribuição do passado no presente das mulheres indígenas. Nos escritos de Bray, as mulheres indígenas contemporâneas são representados como possuidoras de uma ligação ativa e dinâmica com o legado das práticas tradicionais no presente. Como é o caso da resposta da acadêmica para a peça True, as leituras de imagens na peça dependem da posição, das expectativas e as atitudes da plateia.

A diretora euro-australiana Angela Chaplin relata um incidente depois da montagem Road (1996), de Jimmi Chi Corrugation. Em um dado momento da peça, algumas mulheres do elenco dançavam com inspiração as práticas tradicionais. Um colega de Chaplin inclinou-se e disse: "isto é o que eu gosto de vê-las fazendo." ${ }^{34}$ Chaplin reconhece o comentário como um exemplo da tendência em considerar artistas indígenas incorporando culturas do passado à maneira de peças vivas de museu. Embora tal tendência seja aparentemente generalizada, como demonstrado por uma vasta recepção crítica, as suas próprias experiências demonstram o potencial para o diálogo e interação para conduzir à mudança. ${ }^{35}$

...quando eu fui para o norte, na co-
munidade da Ningali. onde fomos
para escrever a peça [Ningali],uma
noite sentamos em volta da fogueira
com as suas tias e avós e elas con-
tavam histórias. Elas as estavam
contando na sua língua e Ningali es-
tava traduzindo para nós. Eu estava
ficando completamente empolgada
com o momento e pensando que eu

34 CHAPLIN, Angela. Reconciliation and the Performing Arts: Proceedings of the Melbourne Forum In: GARDINER, Greg ; ECKERSALL, Peter. (Orgs.), Discussion Paper, Monash University Koorie Research Centre, N. 11, 2000, p. 20.

35 Para aprofundar a discussão da recepção do trabalho de escritores indígenas ver: CASEY, Maryrose. Creating Frames: Contemporary Indigenous Theatre, UQP, 2004. 
era a pessoa mais sortuda do mundo. Elas me contavam histórias incríveis e muitas delas estavam sonhando histórias e mais histórias sobre eventos históricos. Então, Ningali começou a rir e eu disse: "o quê?", e ela disse: Ah, elas estão falando sobre o Michael Jackson e a Lisa Marie Presley e se eles fazem sexo ou não. Para mim, naquele momento, o comentário acertou em cheio, quero dizer que eu estava sentada com aquelas mulheres que não falavam inglês, que moraram no mesmo pedaço de terra por todas as suas vidas, mas elas não eram peças de museu. Acho que isso é tão importante que o nosso trabalho deve refleti-1o. ${ }^{36}$

A viagem de Chaplin à região de Kimberly foi feita para realizar a pesquisa de colaboração criativa com Ningali Lawford e Robyn Archer, baseada na vida de Ningali. O resultado foi o monólogo chamado Ningali (1994). Ningali nasceu em WA, Wangkatjungaka Christmas Creek Station, perto de Fitzroy Crossing, em Kimberley. Seu pai era criador de gado e ela cresceu no campo, falando walmaajarri, o idioma de sua avó materna. Ela foi criada dentro das regras do deserto ocidental e suas tradições. Como Ningali observou, o seu povo estava entre "os últimos alcançados pelos colonizadores, então a nossa língua e a nossa cultura puderam se manter em grande parte, intactas." ${ }^{37}$ Ningali teve pouco contato com a Austrália não-aborígene até a sua adolescência. Aos 13 anos ela foi enviada à um colégio interno em Perth, que estava $2.500 \mathrm{~km}$ ao sul. Aos 16 anos, ela se candidatou, "mais por brincadeira", para uma bolsa de estudos de intercâmbio para os EUA. Questionada sobre qual o destino de sua preferência, ela escolheu Hollywood. Era o único lugar do qual ela havia ouvido falar nos EUA. A bolsa, que foi oferecia a ela, não era para Hollywood, mas para o Alasca, e ela a aceitou. Como Ningali diz em sua peça, ir para o Alasca

${ }^{36}$ CHAPLIN, Angela. In:__ . Reconciliation and the Performing Arts, p. 20.

${ }^{37}$ Ningali Lawford, entrevista pessoal, Melbourne, 12 abr. 2000. "foi uma verdadeira aventura para uma menina cuja língua não possui uma palavra para a neve". ${ }^{38}$ Depois de terminar a escola, não demorou muito para Ningali descobrir que ela queria ser artista. Ela foi para Sydney para estudar na NAISDA. Como atriz e dançarina, ela trabalhou extensivamente em teatro e cinema, incluindo Bran nue dae (1990) de Chi, My spiritual dreaming (1992), de Eddie Bennell, bem como em seus próprios trabalhos, Ningali e Solid (2000). Em 2000, Ningali viajou pela Malásia com uma coletânea de canções e danças de Black swan. Desde então, além de trabalhar em produções para a maioria das grandes companhias, Ningali criou e atuou em Black and tran (2001) com Hung Lee, no Melbourne Comedy Festival e Solid, no Perth Arts Festival 2000, realizando turnês.

Ningali, o trabalho criado com Archer e Chaplin, trata do seu lar e infância, das suas histórias de família, do tempo que passou no Alasca, da sua formação em Sydney e da visita à sua família em Fitzroy Crossing. Entrelaçados a estes eventos estão a dor da perda, a discriminação e a repressão. $\mathrm{O}$ trabalho obteve sucesso e foi bem recebido. Ningali foi realizado em Fremantle, Perth, Canberra e Melbourne, em 1994. Em 1995, a peça fez turnê para o Edinburgh Festival, no Reino Unido e na Alemanha. Ningali ganhou entre outros, o prêmio de melhor produção do Edinburgh Festival em 1996, e obteve sucesso de crítica na Europa e na Austrália. A peça também foi apresentada no Festival of the Dreaming, em 1997.

De acordo com Ningali, cabe às "minorias informar e esclarecer as maiorias". ${ }^{39}$ Esse é o desafio que Ningali enfrenta em seu trabalho criativo. As autobiografias de mulheres indígenas foram identificadas dentre vários gêneros, como um poderoso desafio para os preconceitos, por "declararem seu gênero e a marginalidade de sua raça, e da mesma forma reivindicarem o

\footnotetext{
38 LAWFORD, Ningali; ARCHER, Robyn; CHAPLIN, Angela, Ningali, direção de Angela Chaplin, ocorrida na The National Performers Conference October 1994, Beckett Theatre at the Malthouse; 'Ningali', Wimmin's Business, Festival of the Dreaming, Opera House, Sydney, 23 Set. 1997.

39 Lawford, entrevista pessoal.
} 
verdadeiro valor da subjetividade" ${ }^{40} \mathrm{He}-$ len Thomson argumentou que as "autobiografias de mulheres indígenas encenadas dão corpo a uma poderosa "réplica", um ato de descolonização". ${ }^{41}$ Esta interpretação é bem demonstrada por Ningali. No seu trabalho, Ningali aborda o público diretamente, contando histórias em várias línguas: walmaajarri e wangkatjungaka (línguas tradicionais), inglês (que ela aprendeu quando tinha treze anos) e kriols locais. Ela compartilha o riso, a raiva e a mágoa em um monólogo que poderosamente (re) apresenta uma mulher inteligente e sensível, que tem negociado de maneira bem sucedida com um mundo frequentemente hostil. Movendo-se no palco, enérgica e articuladamente, ela ataca premissas relativas à raça e aos preconceitos. Ao mesmo tempo, ela reconhece os problemas e questões sociais dentro de sua comunidade. A presença de Ningali no palco enfrenta representações fixas e o uso que faz de suas histórias e de sua língua, quebra o silêncio do racismo.

Ningali é um de uma série de monólogos de sucesso criados em colaboração e realizado por mulheres australianas indígenas na década de 1990. Muitos destes monólogos são em grande parte autobiográficos. Assim como Ningali, esta série inclui What do they call me? (1990), de Eva Johnson, 7 stages of grieving (1994), de Wesley Enoch e Deborah Mailman, Oh my god i'm black (1995), criado por Maryanne Sam, Patricia Cornelius e Irine Vela, White baptist abba fan (1997), de Deborah Cheetham, Box the Pony (1997), de Leah Purcell e Scott Rankin.

Quatro destes monólogos obtiveram sucesso no Festival of the Dreaming, em 1997. Ningali, 7 stages of grieving, White baptist abba fan e Box the Pony eram parte de uma série chamada Wimmin's Business. O programa, anunciado como "Seven women, seven stories", consistia de sete monólogos de artis-

\footnotetext{
40 THOMSON, Helen. Aboriginal Women's Staged Autobiography. In: MAUFORT Marc BELLARSI Franca. (Orgs.). Siting The Other: Re-visions of Marginality in Australian and Canadian Drama. PIE- Peter Lang, 2001, p. 25; ENOCH, Wesley; MAILMAN, Deborah. 7 Stages of grieving, Playlab Press, 1996, p.73

41 THOMSON,Helen. Aboriginal Women's Staged Autobiography, p. 35.
}

tas indígenas da Austrália, Nova Zelândia, Canadá e EUA. As atrizes eram, ou criadoras solo ou haviam escrito/criado o texto, em colaboração com os outros. O grande sucesso dos monólogos do Wimmin's Business no festival resultou em turnês, tanto na Austrália quanto internacionalmente. Estes monólogos compartilham uma motivação básica. Como Mailman expressa, a esperança é que o público vai "sair do teatro com uma compreensão maior de onde [os aborígenes] vêm e entender que a luta ainda é forte para nós". ${ }^{42}$

O número significativo de monólogos no Festival of the Dreaming partiu de uma decisão ativa do diretor artístico Rhoda Roberts.43 Roberts propôs para algumas artistas indígenas que elas realizassem trabalhos em colaboração com escritores com base em suas biografias pessoais para fazer parte da programação do festival. ${ }^{44}$ A proposta resultou na realização de White baptist abba fan e Box the Pony. Para Cheetham e Purcell, estas obras representaram as suas primeiras experimentações de escrita para a atuação. As duas eram artistas, Cheetham era cantora de ópera e Purcell era atriz e apresentadora. Ambos os espetáculos fizeram várias turnês após o festival.

O trabalho White baptist abba fan, de Deborah Cheetham é inspirado em suas experiências pessoais. Como membro das "gerações roubadas", foi contado a Cheetham a história falsa de que ela era uma criança abandonada, que a sua mãe a rejeitou: "Ela colocou você em uma caixa de papelão e a deixou no campo." 45 A história de Cheetham explora as dificuldades de se aproximar da própria mãe no primeiro encontro entre as duas, pois Cheethman havia sido

\footnotetext{
42 MAILMAN, Deborah apud TAYLOR, Catherine. Mailman Delivers, Weekend Australians, 25-26 Out. 1997, p. 18.

43 Membro da nação Bundjalung, do clã Wiyebal, de Northern NSW e South East QLD, 0 envolvimento de Rhoda Roberts com as artes é extensivo. Ela é membro co-fundadora da primeira companhia nacional de teatro aborígine, a (Aboriginal National Theatre Trust (ANTT) e como atriz, produtora e diretora, ela continua a trabalhar com teatro, filme, televisão e rádio.

44 O Festival of the Dreaming, realizado em Sydney 1997, foi o primeiro dos festivais de artes organizado como parte do programa cultural das Olimpiadas de Sydney. O Festival foi dedicado às artes dos povos indígenas do mundo, com uma ênfase particular nas artes dos indígenas australianos. Ver ROBERTS, Rhoda. Introduction. The Festival of The Dreaming: Festival Guide, Sydney Morning Herald August, 1997.

45 Wimmin's Business Brochure, Festival of the Dreaming Sydney 1997, s/p
} 
criada em um contexto diferente. Quando ela se encontrou pela primeira vez com sua mãe, ambas trataram-se como "estranhas cheias de preconceitos de ambos os lados". A narrativa do texto segue a "viagem de uma branca batista fã de Abba até a cantora gay koori de ópera". Cheetham coloca uma equipe de colaboradores em conjunto que "lhe convinham". O trabalho final entrelaça árias de ópera com o relato de histórias fortes. ${ }^{46}$

Box the Pony, de Leah Purcell, atingiu grande visibilidade e o texto foi publicado pela Currency Press. Purcell discutiu com Roberts a ideia que ela teve para a montagem da peça com temas do festival como "contemporâneo, íntimo e verdadeiro". Uma vez garantido o financiamento através do comitê Olímpico e da Aboriginal Arts Board, Purcell procurou um escritor para colaborar com o processo..$^{47}$ Box the Pony fala sobre a história dos Murri, de Queensland e foi escrito em colaboração entre Purcell e Scott Rankin. Purcell escolheu um euroaustraliano para colaborar, porque, como ela costuma dizer, ela "queria ver o que o outro lado da moeda tinha para oferecer" à história de uma mulher murri. ${ }^{48}$ Após o sucesso no Festival of the Dreaming, Box the Pony foi apresentado no Belvoir St Theatre, na Sydney Opera House, no Edinburgh Festival de 1999 e em uma sessão no Barbican Theatre dentro das celebrações do London for Centenary of Federan, em 2001. O texto da peça foi aclamado pela crítica, ganhando o prêmio de melhor peça, tanto no 1999 NSW como no 2000 Queensland Premier Literary Awards. Além disso, o texto foi premiado no Human Rights Arts Award, em 1999. Purcell foi indicada na inauguração do 2001 Helpmann Awards como melhor atriz por seu trabalho em Box the Pony.

Box the Pony é uma semi-biografia baseada na vida de Purcell. A vida de Purcell é descrita como uma verdadeira história

\footnotetext{
${ }^{46}$ BLACKLOCK, Wendy. Director Performing Lines, entrevista pessoal, Sydney, 23 set. 1997.

${ }^{47}$ ALLEN, Olivia. Going Solo. Dialogue 33, Dez 1997, s/p.

48 PURCELL, Leah. Introduction. In: PURCELL, Leah; RANKIN, Scott Box the Pony, Sceptre/Hodder Headline Australia, 1999, p.01.
}

da miséria à riqueza. ${ }^{49}$ Crescendo na zona rural de Queensland, Purcel usava roupas de brechó e passou noites vendo a sua mãe voltar do bar cambaleando. Seu pai, um professor de boxe euro-australiano, tinha uma mulher euro-australiana e filhos, mas teve outras seis crianças com a sua mãe, uma aborígene vinda do povo Goa gungurri wakka wakka. Purcell foi mãe solteira quando tinha 18 anos e com 20, fugindo de um namorado que bebia e era violento, se muda com a filha Amanda, para Brisbane. Lá, ela começou a construir a sua carreira nas artes do espetáculo. Seu primeiro grande trabalho foi em 1993 no Bran nue dae (1990), que excursionou pela Austrália. Seguiram-se mais trabalhos de teatro e, em 1995, ela se muda para Sydney, tornandose a primeira apresentadora do RED Music Channel no Galaxy Pay TV. Em Sydney, ela trabalhou em vários programas de televisão. Em 1997, Purcell foi indicada ao prêmio de melhor atriz (dramática de televisão) no Australian Film Institute (AFI) Award, por sua atuação em Fallen Angels (no TV Drama). Outros méritos seus incluem a produção de Marriage of Figaro do Olympic Arts Festival, em 2000 e o filme Lantana, de 2001.

Para Purcell, Box the Pony analisa as tensões interculturais e inter-raciais na Austrália rural pela ótica de sua própria infância. A narrativa é uma contação de histórias de estilo ativo endereçado diretamente à plateia. No monólogo, Purcell interpreta dezessete personagens ou grupo de personagens. A música complementa a narrativa das histórias. As línguas usadas no texto incluem a língua murri, o inglês murri e o inglês clássico. A narrativa estrutura-se em duas histórias. Uma, em primeira pessoa, é a história da personagem principal, uma versão de Purcell, e o vôo da sua Datsun Sunny rumo à fama, em Sydney. Purcell compartilha as suas experiências de Woollahra com um olhar bem-humorado sobre os preconceitos nos cafés e nas ruas, sua iniciação no mundo da televisão e sua

\footnotetext{
49 COLEMAN, Sarah. Leah Purcell. Telling Aboriginal Stories, World Press Review, V. 50 N. 8 , ago. 2003
} 
ascensão ao estrelato com direito a estilistas pessoais. A outra história, narrada por Purcell, é de Steffie, sua amiga e alter-ego, de volta à Murgon, Queensland. Purcell conta a história de Steffie desde a infância até a sua tentativa de suicídio, em Datsun Sunny..$^{50}$

A história dos "bons tempos, tempos difíceis e tempos tristes" é contada com humor. A sequência da Miss Murgon, em que Steffie concorre com sucesso ao título de Miss Murgon, é um trecho cômico extraordinário da história que revela camadas sobre a pobreza e a vida na cidade do interior na visão de uma menina murri. No texto, o tema central é o relacionamento entre Purcell e sua mãe alcoólatra, particularmente, a bebedeira de sua mãe e a morte. Este relacionamento é o pano de fundo para a gravidez precoce de Steff, o namorado violento e o desespero que a levou a tentar acabar com a sua vida e a de sua filha. A separação da narrativa em duas pessoas permite a Purcell "trazer a história para fora do seu contexto, comentá-la e retornar para a mesma" ${ }^{51}$ A dor e o humor da história são compartilhados entre o público e Leah, personagem central, permitindo que o público reconheça a identidade de Steff. O texto transmite a mensagem de que um espírito forte nunca perde o sorriso e o bom-humor assim como ela, que lutou contra a dor, mantendo a alegria de viver.

As memórias de Purcell e as associações emocionais de sua infância e adolescência são dadas de forma física no palco. Foi usado couro de vaca para cobrir o palco e também para representar outros personagens, reproduzindo as memórias que Purcell tinha dos abatedouros e das peles jogadas sobre as cercas de arame farpado ao longo da estrada, perto de onde ela cresceu, em Murgon. O boxe desempenhou um grande papel em seu crescimento. Todos os rapazes tinham a esperança de transformar suas vidas fazendo sucesso nos ringues e

50 Eu discuto essa peça e outros monólogos em: CASEY, Maryrose. Performing Indigenous Women. Hecate's Australian Women's Book Review, V. 11, 1999, p. 41-43 CASEY, Maryrose. Creating Frames: Contemporary Indigenous Theatre 1967-97. UQ Press, 2004.

51 PURCELL, Leah. Introduction.In: Box the Pony, p. 3 foi decepcionante para Purcell ver que este caminho estava fechado para ela. Este domínio do esporte foi reproduzido no espetáculo pela colocação de um grande saco vermelho de pugilistas no centro do palco. Um grande tapete azul ecoando o azul intenso do céu de Queensland completaram o set. ${ }^{52}$

Além de ser autobiográfica, Box the Pony, assim como Ningali e White baptist abba fan, apresenta a sobrevivência ativa e positiva de um indivíduo. A performance de Purcell em Box the Pony, no Belvoir, foi promovida e discutida baseada no que Purcell como indivíduo descreveu como "uma força com a qual se tem que lidar" e "destemido". ${ }^{53}$ A discussão de Purcell, e de seu trabalho, incluiu uma jornalista que expressou sua dificuldade em acreditar que Purcell poderia ser qualquer coisa, menos bem sucedida. ${ }^{44}$ Se por um lado, esses espetáculos estão (re)presentando indivíduos bem-sucedidos, por outro, eles também estão representando mulheres australianas indígenas bem-sucedidas. Mesmo sendo consideradas como um conjunto de exceções, essas representações ainda assim contestam representações generalizadas que tratam todas as mulheres indígenas como se todas fossem iguais. Como indivíduos, essas artistas e suas histórias se opõem ativamente contra representações fixas de mulheres indígenas como silenciosas e impotentes.

Estes monólogos fazem parte e contribuíram para uma série de alterações na elaboração do trabalho indígena nas artes do espetáculo. Como afirmado anteriormente, o trabalho teatral de artistas indígenas tem consistentemente contestado as construções externas de aboriginalidade impostas a partir de uma gama de posições. Mechanics of the spirit, de Bray, é um exemplo de reivindicação de um artista a partir da co-

\footnotetext{
52 PURCELL, Leah. Introduction. In: Box the Pony; PURCELL, Leah; RANKIN, Scott. Box the Pony. Wimmin's Business Festival of the Dreaming Opera House, Sydney, 20 set. 1997

53 FENSHAM, Rachel. Farce or Failure, Theatre Research International V. 26 N. 1, mar. 2001, p. 90.

54 LANCASHIRE, Rebecca. The Struggle of Life Takes Centre Stage, Age 20 out. 1998, p. 17.
} 
nexão de seu trabalho com crenças e práticas tradicionais. De uma forma diferente, estes monólogos contestaram emoldurações que tratam as práticas tradicionais e aboriginalidade como peças de museu, comandando um espaço contemporâneo e de novas construções Isto tem levado a uma série de resultados concretos que indicam mudanças nas expectativas e suposições sobre mulheres artistas indígenas e seus trabalhos. Quando Ningali foi produzido pela primeira vez, houve uma tentativa de enquadrá-la em relação às associações tradicionais de espetáculos, usando fotos que mostram o rosto pintado de branco ocre..$^{55}$ Ningali resistiu a esse tipo de enquadramento sobre ela e o seu trabalho. Isso foi em 1994. Em 1997, quando Purcell estava apresentando Box the Pony, não havia dúvida de tentativa de enquadramento de seu trabalho no âmbito deste tipo de construção. As fotos publicitárias exibiam uma mulher sorridente, forte e contemporânea. Este enfoque sobre o papel e da presença de indígenas dentro das artes e da sociedade contemporânea era uma característica do Festival of the Dreaming, conforme concebido por Roberts, da mesma maneira como é característica do monólogos criados por mulheres indígenas. Cumulativamente, a dinâmica entre as representações e preconceitos externos foi alterada. Estes monólogos contribuíram para a criação de um espaço para as mulheres indígenas artistas. Especificamente, um resultado foi uma gama maior de papéis disponíveis para as próprias artistas. Purcell e Mailman em particular, abriram novos caminhos no teatro, cinema e televisão, com papéis em textos europeus clássicos, como The Marriage of Figaro (Purcell) e Lear (Mailman). Ningali inovou criando stand-up comedies.

As mulheres indígenas têm desempenhado um papel importante ao provocar e facilitar essas mudanças de expectativas e oportunidades. Ao mesmo tempo, elas têm continuado a se engajar em difíceis materiais de conteúdo emocional e político no palco. Purcell começou a pensar seria-

${ }^{55}$ CHAPLIN, Angela. diálogo, Perth, abr. 1999. mente sobre identidade quando ela estava trabalhando em Box the Pony. Um dos resultados de seu trabalho foi um projeto de pesquisa baseado em entrevistas que culminou em um livro chamado Black chicks talking (2002). Para este livro, Purcell entrevistou nove mulheres indígenas jovens e bem sucedidas em diversas profissões. As origens variam, algumas alcançaram um alto grau de sucesso nos esportes e nas artes, e outras estão trabalhando para melhorar a vida dentro das comunidades indígenas ou para manter suas tradições. As entrevistadas são: Deborah Mailman, atriz; Frances Rings, bailarina; Rachel Perkins, diretora de cinema; Sharon Finnan, jogadora de Netball; Tammy Williams, advogada; Rosanna Angus, uma mulher tradicional do povo Bardi do Oeste da Austrália que trabalha como a delegada da sua comunidade; Cilla Malone, que cresceu em uma missão em Queensland e que superou abuso de drogas; Liza Fraser-Gooda que abriu a Jinnali Modelling, uma agência que representa mulheres indígenas e que produziu o primeiro calendário de mulheres indígenas vestidas de biquíni; e Kathryn Hay que foi coroada Miss Austrália e assim se tornou a primeira indígena a ganhar a competição. As entrevistas documentadas no livro são uma troca ativa entre entrevistadora e objeto de pesquisa. Purcell contribui e revela suas experiências e descobertas para as mulheres enquanto fala com elas. O livro provou ser bem sucedido e foi a base para vários outros projetos. De outras entrevistas, Purcell produziu um documentário e concebeu uma peça, ambos também foram chamados de Black chicks talking.

O documentário foi feito enquanto Purcell finalizava o livro e é uma versão reduzida do projeto, focando em cinco das mulheres. Purcell então adaptou as histórias de suas entrevistas para o palco com cinco personagens que estreou em Brisbane em 2002. Após aquela temporada, Black chicks talking, escrita e dirigida por Leah Purcell, em colaboração com Sean Mee, produzida em associação com Bunjara Productions, foi apresentada no Sydney Festival e no Perth 
Festival, em 2003. A produção foi feita em conjunto com uma exibição de fotografias que Robert Hannaford fez das mulheres entrevistadas, além de uma exibição multimídia.

Black chicks talking, é parte da mesma conversa que True. A peça explora questões de pertencimento, identidade e família, não apenas como elas se relacionam ao contexto indígena, mas também como elas se relacionam a um contexto australiano mais amplo. Ainda, como True, Black chicks talking, lida com a dor sentida pelas Gerações Roubadas e as gerações seguintes que carregaram o mesmo legado. Na peça cinco mulheres se encontram em um espaço espiritual, cada uma buscando resolver problemas de identidade e pertencimento. Elas vêm de diferentes lugares, diferentes posições sociais e diferentes grupos, desde a sofisticação urbana até as comunidades indígenas. Na produção em um cenário simples, mas visualmente forte, ouvindo a história de uma as outras, cada mulher passa a ver seu próprio mundo de forma diferente. $\mathrm{O}$ cenário, descrito no programa como um 'solo antigo', consistia de um enorme galho de uma árvore Ghost gum. ${ }^{56}$ Um branco brilhante domina o palco criando um espaço que é ao mesmo tempo estranho, antigo e ainda neutro e inclusivo.

Como True, a exploração da identidade e do pertencimento de Black chicks talking lida com a categorização da cor da pele e dos problemas da separação da cultura. A personagem Elizabeth (interpretada por Purcell) vê sua história nos termos da linguagem colonial/imperial de raça (sangue puro, mestiço, filhos de mulatos com brancos). Ela descobriu que é 'parte' aborígene. $\mathrm{O}$ diálogo espirituosamente toca nesta descrição com a questão - "qual parte?"57 O texto então revela que o senso fragmentado de si da personagem é o resultado de sua separação e ignorância a respeito das comunidades indígenas e suas culturas.

56 Centrestage Diary of Events, QPAC nov-dez. 2002; PURCELL, Leah In:__ . Collaboration with Sean Mee, Black chicks talking, dirigido por Leah Purcell, produzido por La Boite Theatre and QPAC Association com Bungabura Productions, Optus Playhouse, Brisbane, 12 dez. 2002

57 PURCELL, Leah. Black chicks talking, Optus Playhouse.
Sua mãe reprimiu sua identidade cultural, deixando Elizabeth sem histórias e conhecimento. Ela, portanto, se sente inautêntica e vulnerável na identidade que ela ao mesmo tempo adota para si e luta para se entender.

O personagem Elizabeth é baseado nas entrevistas feitas com Kathryn Hay contidas no livro. A busca da tasmaniana Hay por sua própria identidade é a parte central do livro. Sua entrevista e discussão com Purcell é um exemplo real e comovente de uma pessoa questionando sua identidade e seu lugar no mundo, em especial a sua tentativa de fazer as pazes com os tipos de classificação que ela recebeu. Por exemplo, quando Purcell a questiona na entrevista sobre sua aboriginalidade, as duas mulheres acabam demonstrando posições diferentes. As posições que Black chicks talking e True levam ao palco.

Kathryn: A mãe da minha mãe - e eu acho que a mãe dela - eram aborígenes ou parte aborígenes. Eu tenho 1/16 de sangue aborígene, então minha mãe é meia-casta... é, e então ela...

Leah: Espera um minuto, pare com isso! Você tem que parar com essa conversa, Kathryn!

Kathryn: Mas é assim que eles nos categorizam ou nos classificam. ${ }^{58}$

Na peça Black chicks talking, Purcell usa de forma sagaz os estereótipos criados sobre uma variedade de diferentes mulheres indígenas para explorar a questão da identidade e das dificuldades enfrentas por indígenas de pele clara e por indígenas que foram criados fora das culturas indígenas. Elizabeth parece 'branca', e, no entanto, como ela diz, ela é "parte aborígene". As outras quatro mulheres que possuem pele mais escura a repreendem por utilizar esta terminologia, mas Elizabeth sente que ela não pode se intitular aborígene porque ela não sabe nada sobre os modos e conhecimentos aborígenes. Ela gosta de seu celular e de seu trabalho bem remunerado das 9

58 PURCELL,Leah. Black chicks talking, Hodder, 2002, p. 213. 
as 5, e sente que não possui conexões com a sua ancestralidade aborígene. As outras personagens lutam de maneiras diferentes com suas identidades e senso de pertencimento. Tem a Patrícia, uma implicante estudante radical. Michele é uma garota de 'missão', que faz piada sobre ser o estereótipo aprovado pelo governo- sete filhos de cinco pais, adicionados ao problema com álcool e drogas. E tem Sophie imaginando se ela pode ser autenticamente indígena com uma casa, um carro com tração nas quatro rodas e uma lavadora de roupas, ecoando as objeções da estudante euro-australiana em relação a True. Apenas uma das personagens, Michelle, cresceu com uma forte conexão com a cultura, 'ouvindo as histórias do povo antigo'. A quinta personagem, Janine, assiste a ação à distância. Incorporando a presença da perda e da dor, ela representa crianças que foram retiradas de suas famílias ou dadas para adoção. Janine é irmã de Patrícia e foi retirada da família, e também representa simbolicamente a filha de Michelle que lhe foi tomada. Por analogia, ela representa todas as crianças tolhidas da tradição oral de seus ancestrais, das histórias que são a base de seu pertencimento e sua identidade.

Como em True, a conclusão é que aboriginalidade refere-se ao indivíduo independente das classificações, categorias ou qualquer outra conclusão externa. Nas palavras de Leah Purcell:

Hey, não se enquadre, amiga! Você é uma mulher negra e ponto. A Austrália deve aceitar que os índios australianos vem em todas as formas, tamanhos e cores. Ser um negão na sociedade de hoje não tem nada a ver com a cor da sua pela, é sobre o que você tem no seu coração e na sua alma. ${ }^{59}$

Todas as peças e performances discutidas aqui oferecem insights pessoais sobre as experiências e as histórias pessoais, emocionais e culturais dos indígenas australianos. Como a maioria dos escritos de mulheres indígenas, os textos são mar- cados por humor, coragem e honestidade. Eles mostram uma perspectiva indígena de como as mulheres indígenas se enxergam e olham para as suas comunidades, e oferecem seus trabalhos para comunidades indígenas e não indígenas. Mas elas escrevem primeiramente e principalmente para os povos indígenas e apresentam as mulheres não como objetos passivos, mas como sujeitos ativos e articuladores. Como Sherriff apontou em relação à True, essas dramaturgas abordam problemas que geralmente não são discutidos. Elas exploram o legado de mentiras e negações, além da luta dos indivíduos para lidar com questões importantes sobre identidade e pertencimento. Ao longo do processo essas escritoras criam novas histórias que fornecem o potencial de cura e de mudança tanto para indígenas quanto para australianos não indígenas. Essas novas histórias enfatizam um amplo campo de novas representações de mulheres indígenas na Austrália e oferecem a base para novos formatos de identidade e pertencimento.

${ }^{59}$ PURCELL, Leah. Black Chicks Talking, Hodder, 2002. p. 213. 
